This article was downloaded by: [Sang, Guoyuan]

On: 15 October 2009

Access details: Access Details: [subscription number 915863608]

Publisher Routledge

Informa Ltd Registered in England and Wales Registered Number: 1072954 Registered office: Mortimer House, 37-41 Mortimer Street, London W1T 3JH, UK

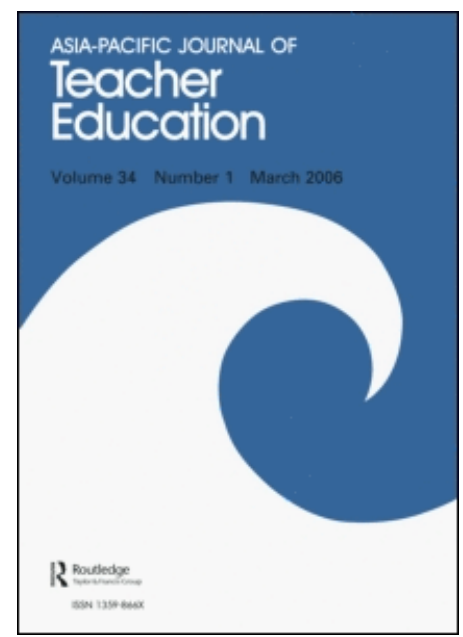

Asia-Pacific Journal of Teacher Education

Publication details, including instructions for authors and subscription information:

http://www.informaworld.com/smpp/title content=t713405488

\title{
Investigating teachers' educational beliefs in Chinese primary schools: socioeconomic and geographical perspectives
}

Guoyuan Sang a; Martin Valcke a; Johan van Braak a; Jo Tondeur a

a Department of Educational Studies, Ghent University, Belgium

Online Publication Date: 01 November 2009

To cite this Article Sang, Guoyuan, Valcke, Martin, van Braak, Johan and Tondeur, Jo(2009)'Investigating teachers' educational beliefs in Chinese primary schools: socioeconomic and geographical perspectives',Asia-Pacific Journal of Teacher Education,37:4,363 — 377

To link to this Article: DOI: $10.1080 / 13598660903250399$

URL: http://dx.doi.org/10.1080/13598660903250399

PLEASE SCROLL DOWN FOR ARTICLE

Full terms and conditions of use: http://www.informaworld.com/terms-and-conditions-of-access.pdf

This article may be used for research, teaching and private study purposes. Any substantial or systematic reproduction, re-distribution, re-selling, loan or sub-licensing, systematic supply or distribution in any form to anyone is expressly forbidden.

The publisher does not give any warranty express or implied or make any representation that the contents will be complete or accurate or up to date. The accuracy of any instructions, formulae and drug doses should be independently verified with primary sources. The publisher shall not be liable for any loss, actions, claims, proceedings, demand or costs or damages whatsoever or howsoever caused arising directly or indirectly in connection with or arising out of the use of this material. 


\title{
Investigating teachers' educational beliefs in Chinese primary schools: socioeconomic and geographical perspectives
}

\author{
Guoyuan Sang*, Martin Valcke, Johan van Braak and Jo Tondeur \\ Department of Educational Studies, Ghent University, Belgium
}

(Received 16 October 2008; final version received 6 June 2009)

\begin{abstract}
This empirical study explores the nature of and profiles in primary teachers' educational beliefs in the Chinese educational settings. A survey of 820 primary school teachers was conducted using a questionnaire focusing on teachers' traditional and constructivist beliefs about teaching and learning. Analysis of variance and cluster analysis were applied. Results show that gender and subject domain affect traditional educational beliefs. Significant differences appear considering economic and geographical context variables. Cluster analysis helps to delineate four teacher belief profiles: a constructivist profile, a mixed constructivist/traditional profile, a traditional profile, and a mixed low constructivist/traditional profile. Inter-relation between teacher belief profiles and school categories are discussed.
\end{abstract}

Keywords: educational beliefs; empirical study; primary school; teacher education

\section{Introduction and problem statement}

A growing body of research suggests that teacher beliefs affect teaching practices, classroom judgements and classroom management (Clark \& Peterson, 1986; Richardson, 1996; Shin \& Koh, 2007; Thompson, 1992; Woolley, Benjamin \& Woolley, 2004). For instance, Clark and Peterson (1986) state that 'teacher behavior is substantially influenced and even determined by teachers' thought processes' (p. 255) because teachers' beliefs represent the rich store of knowledge of teachers, affecting their instructional planning and practices. As such, teacher beliefs present a window through which to look at teacher decision making, practices and, in some cases, the efficacy of instructional practices (Nespor, 1987; Pajares, 1992). Hence, a better understanding of educational beliefs of teachers is essential to influence and improve teaching practices and the potential success of educational reforms.

In the Chinese context, research focusing on teacher beliefs started only recently. Especially as a response to dealing with the more complex demands of modern society, educationists and researchers stressed the need to adopt more progressive educational beliefs. They refer, in particular, to the importance of constructivist beliefs about teaching and learning (Lü, 2004; Xie, 2006). This goes together with a shift in the pedagogical paradigm from teaching practices as 'transmission of knowledge' to teaching practices that 'activate' the learner through approaches such as problem-based learning, inquiry learning, collaborative learning etc. According to Pei (2004), teaching strategies of teachers are

*Corresponding author. Email: Guoyuan.sang@ugent.be 
evolving towards this constructivist idea. However, many teachers do not embrace the constructivist paradigm in their daily classroom activities (Cao, 2006). The latter may be explained by inconsistencies between their teaching beliefs and the innovative practices they are expected to adopt (Clark \& Peterson, 1986; Tobin \& McRobbie, 1996). Differences in the adoption of educational reforms can also be related to contextual variables. Teng (2003) refers in the Chinese context to the large diversity in economic and cultural development between the western and eastern provinces and between urban and rural areas in China. Studying educational beliefs in the Chinese context should therefore consider these additional variables.

\section{Theoretical background}

\section{Defining teacher beliefs}

The term 'beliefs' is used in an interchangeable way with concepts as conceptions (Erlwanger, 1975), a philosophy (Ernest, 1991), an ideology, a perception and a world view (Schoenfeld, 1985). Other researchers refer to 'principles of practice', 'personal epistemologies', 'perspectives', 'practical knowledge' or 'orientations' (Kagan, 1992). It is therefore not surprising that Pajares considered it to be a 'messy concept' (1992, p. 307). Because beliefs cannot be observed directly and have to be inferred from behaviour or teacher statements, it is difficult to put forward a precise definition of beliefs (Leder \& Forgasz, 2002). Pajares (1992) argues that the lack of a clear definition and the inconsistent adoption of terminology is a major impediment to progress in research on teacher beliefs.

A belief is a representation of the information someone holds about an object or a 'person's understanding of himself and his environment' (Fishbein \& Ajzen, 1975, p. 131). Beliefs and a beliefs system serve as personal guides in helping individuals define and understand the world and themselves (Pajares, 1992). Also, the nature of teacher beliefs has been characterised in terms of effective, evaluative and episodic processes (Van Driel, Bulte \& Verloop, 2007).

Despite the conceptual confusion, researchers have made attempts to clarify the terminological discussion about teacher beliefs and to centre on profiles in teacher beliefs (Nespor, 1987; Richardson, 1996). Beliefs could be as varied as teaching itself and reflect issues related to learners (e.g. beliefs about inclusion, about diversity), knowledge (epistemological beliefs), teaching components (beliefs about the curriculum, beliefs about what learning content is important, beliefs about instructional media, teaching strategies, evaluation etc.), parents, instructional context and organisational dimensions (Tondeur et al., 2009). Hermans, van Braak and Van Keer (2008) consider these beliefs to centre on three educational issues: (1) The general goals of primary education; (2) the general nature of the educational content; and (3) ways of knowledge acquisition. Woolley, Benjamin and Woolley (2004) distinguish between 'traditional teaching' beliefs and 'constructivist teaching' beliefs of elementary teachers that mirror student-centred approaches to teaching and learning.

\section{Theoretical construct and the structure of teacher beliefs}

Increasingly, improvement efforts in $\mathrm{K}-12$ schools and teacher education programs are based on constructivist theories of learning (Richardson, 1996; Woolley, Benjamin \& Woolley, 2004). Many teacher educators believe that it is important for teachers to 
experience constructivist teaching from a learner's perspective, and then to have opportunities to reconstruct their beliefs about teaching based on their reactions as students. However, as objects of reforming, traditional beliefs and methods still cannot be abandoned by teachers and teacher educators. This bipolar structure of teacher educational beliefs has been discussed by researchers (e.g. Woolley, Benjamin \& Woolley, 2004; Tondeur, Hermans, van Braak \& Valcke, 2008).

Since educational beliefs are related to a variety of educational tenets (see above), researchers have made attempts to delineate prototypical teacher beliefs. In the literature, authors mainly distinguish between 'traditional beliefs' and 'constructivist beliefs' (Kerlinger \& Kaya, 1959; Woolley, Benjamin \& Woolley, 2004). The traditional beliefs are also labelled as teacher-centred (Bramald, Hardman \& Leat, 1995), transmissive beliefs (Hermans, van Braak \& Van Keer, 2008) or subject matteroriented (Billig et al., 1988). These beliefs are adopted by teachers who concentrate on knowledge transmission, devise well-organised teaching plans and adopt step-bystep teaching methods. On the other hand, 'constructivist beliefs' are also referred to as 'supporting student learning' (Samuelowicz \& Bain, 1992), a 'constructivist philosophy of learning' (Bramald, Hardman \& Leat, 1995, p. 24), 'progressive beliefs' (Kerlinger \& Kaya, 1959; Hermans, van Braak \& Van Keer, 2008) or 'student-centred approach' (Bramald, Hardman \& Leat, 1995). Teachers who believe in studentcentred approaches to teaching and learning and concentrate on harmonious development of students and the integration of different subjects can be characterised into this 'constructivist' dimension.

But the bipolar approach to teacher beliefs profiles has, from the start, been criticised by researchers (see, for example, Kerlinger \& Kaya, 1959). Their study provided support for the hypothesis that teachers hold both 'traditionalistic' and 'progressive' educational beliefs. Green (1971) suggests that people tend to order their beliefs in clusters, which are 'more or less in isolation from other clusters and protected from any relationship with other sets of beliefs' (p. 48). Consequently, people can hold conflicting beliefs; for example, about the need for competition and the importance of learner collaboration (see Van Driel, Bulte \& Verloop, 2007). Recently, Tondeur et al. (2008) have also concluded that primary school teachers adopt concurrent educational beliefs, and 'specific beliefs profiles can be identified in teachers, based on the extent to which they adopt traditional and constructivist teaching beliefs' (p. 84).

\section{Endogenous variables affecting educational beliefs: teacher characteristics}

Teachers seem to adopt different educational beliefs, depending on their gender (Kalaian \& Freeman, 1994; Lin, 1992), their teaching experience (Shaw \& Cronin-Jones, 1989; Wood \& Floden, 1990) or the subject domain they teach (Brown, 1985).

Earlier research points to clear gender differences in educational beliefs. For example, Kalaian and Freeman (1994) argue that gender differences in self-confidence and educational beliefs play a role in student teacher persistence and program completion. Gender differences in the beliefs of Chinese primary school teachers are also reported by researchers (see Lin, 1992; Lü \& Wang, 2004).

The variable teaching experience of pre-service and in-service teachers seems to affect beliefs about the role and position of learners in the instructional context; that is, to what extent can we handover responsibilities to learners (Brousseau, Book \& Byers, 1988). The level of teaching experience reflects the extent of teacher reflections on their own practices. Also, teacher beliefs appear to be heavily influenced by actual teaching practices (Zahorik, 
1987). Furthermore, in the Chinese context, teachers' teaching experience is related to their professional qualifications. According to Xiong (2001), the lowest qualification required to become a primary teacher has been changed from 'middle normal school diploma' to 'college diploma'. Thus, teaching experience is negatively correlated with teachers' level of qualification.

The subject a teacher is expected to teach is also expected to be an influencing factor on teachers' educational beliefs (Wood \& Floden, 1990). Teacher beliefs are expected to be mediated by epistemological differences that are inherent to respective content areas or by the instructional materials (Wood \& Floden, 1990).

\section{Exogenous variables affecting teacher beliefs: socioeconomic and geographical factors}

Little research evidence is available regarding macro-level contextual variables that are expected to affect teacher beliefs. The geographical teaching area (rural/urban) where teachers teach has been reported to be an important influencing factor on teachers' beliefs. The institutional context in which teachers work has an effect on the educational beliefs of teachers (Lim \& Torr, 2007). For instance, Martin and Yin (1999) examined differences in classroom management beliefs and found that rural teachers adopted a teacher-induced interventionist instructional approach to a significantly higher extent compared with urban teachers, who adopted a significantly more student-based interventionist approach. A hidden variable in the former study is whether schools are positioned in a developed or developing province. The effect of this variable is seen again in the study of Geng, Feng, Shen and Zhang (2006), who argue that school location and the related school size is expected to have an effect on primary teachers' educational beliefs, which are shaped and developed by teachers culturally and geographically.

The critical importance of school categories has been underpinned by earlier research that links school performance to the underdevelopment of certain Chinese provinces. The 'Chinese Western Development Drive Policy' focuses in this context on 12 underdeveloped provinces. These provinces comprise $28.8 \%$ of the Chinese population, living in $71.4 \%$ of China's regions (CPG, 2000). Teachers are influenced by local educational policies, which are expected to be heavily affected by these differences in developmental level (Teng, 2003). Diversities and differences between urban regions and rural regions, between developed regions and developing regions have been discussed in view of teacher opinion, which states that teachers in underdeveloped areas hold more traditional views (e.g. Pei, 2004); subcultures, which argues that western ethnic minority school teachers are net in their subcultures (e.g. Teng, 2003); and economic development, which indicates the big distance between western regions and eastern regions, between rural areas and urban areas (e.g. Zhu, 2003).

\section{Cultural perspectives on educational beliefs}

Although the present study does not focus on cross-cultural differences in teachers' educational beliefs, culture is an important variable in discussions about beliefs. Considering the nature of beliefs, teachers' educational beliefs may be largely shaped by culturally shared experiences and values. Teaching is a cultural activity and thinking about teaching and learning is informed by culturally shared ideas about teaching and learning (Correa et al., 2008; Stigler \& Hiebert, 1999). Culturally shared educational beliefs of teachers may be so ubiquitous and familiar that they become difficult to recognise (Correa et al., 2008). Correa et al. (2008) explored the differences and 
similarities in mathematics beliefs of primary teachers in China and the United States. They state that Chinese and American teachers have distinct beliefs about teaching and learning. Furthermore, teacher beliefs about teaching and learning are consistent with broader values within a culture or shared as 'primordial values', such as individualist, community or collectivist orientations (Alexander, 2001). For instance, the Chinese social values have been essentially influenced by Confucianism philosophy. Confucianism emphasises traditional values rather than new notions. This tradition might affect in an (in)direct way choices teachers make about instructional practices (e.g. individual versus group work), the extent to which responsibilities are taken over by learners, the nature of assessment etc. Building on this rationale, it will be interesting to analyse the results of the present study in order to see whether the beliefs and belief profiles in Chinese teachers reflect what has been found in Western teachers.

\section{Research questions}

Teachers hold implicit theories (beliefs) about students, the subjects they teach and their teaching responsibilities, and these implicit theories influence teachers' reactions to teacher education and to their teaching practices (Ashton, 1990). Furthermore, development of students and the success of educational reforms also rely on the understanding and changing of teachers' educational beliefs (Pei, 2004). The ultimate objective of the present study is to construct a portrayal of the nature and structure of Chinese teachers' educational beliefs for use by educational researchers, policy makers, teacher educators and school administrators, and to explore the differences in teachers' educational beliefs and profiles between urban and rural primary schools in developed and developing areas in China, and between the four school categories (teachers from urban schools in developed areas; teachers from rural schools in developed areas; teachers from urban schools in developing areas; and teachers from rural schools in developing areas). The following research questions guide the present study:

1. What is the nature of teachers' educational beliefs and to what extent are these beliefs affected by endogenous teacher-related variables (gender, teaching subject, teaching experience)?

2. To what extent are teachers' educational beliefs related to exogenous variables (i.e. urban versus rural schools; developed versus developing provinces; and the four school categories)?

3. What profiles can be delineated by Chinese teachers' educational beliefs?

4. To what extent do those profiles link to the four school categories?

\section{Method}

We adopted a quantitative approach to first develop an understanding of the nature and structure of educational beliefs currently adopted by Chinese teachers. In this context, we adopted a survey methodology that is based on the administration of questionnaires.

\section{Instruments}

To determine the educational beliefs of Chinese teachers, the 'Teacher Educational Beliefs' scale (TEB) was administered. The TEB is based on two available instruments developed in Western educational settings: the 'Beliefs about Primary Education Scale' 
(BPES) (Hermans, van Braak \& Van Keer, 2008) and the 'Teacher Beliefs Survey' (TBS) (Woolley, Benjamin \& Woolley, 2004). The recommended translation procedure 'backtranslation' was applied to the development of the instrument (Hambleton, 1992). In total, 18 items from the BPES (15 of the original 18 items) and the TBS (three of the original 21 items) were selected, after discussions about the interpretation of the test items with six Chinese educationalists and 10 Chinese primary school teachers on the two translated instruments.

The TEB items request teachers to indicate on a Likert scale the extent to which the expression is applicable to them. Typical constructivist belief (CB) items are: 'The learning process always has to start from the learning needs of the pupils' and 'Learners must get the opportunity to build up their own knowledge in a collaborative way or together with the teacher'. Typical traditional belief items (TB) are: 'The content of a lesson has to be completely in line with the curriculum' and 'Lecturing by teacher is more efficient than students' inquiry'.

Although the TEB was developed after a careful translation process and a screening of the items in view of an adequate interpretation, further quality control was necessary because of the Chinese translation and differences in the number of items when compared with the original instruments. Three constructivist items that loaded inconsistently on the traditional dimension were removed from the scale. For example, the constructivist item 'The emphasis on cross-curricular goals is important in primary education'. Three other items were discarded owing to communalities being too low. Adaptations resulted in adequate validity of the final version of the instrument. In addition, the final TEB version reflects a high internal consistency level for both the subscale ' $\mathrm{CB}$ ' $(\alpha=0.81)$ and the subscale 'TB' $(\alpha=0.70)$.

\section{Research sample}

A total of 1000 teachers in Chinese primary schools were invited to participate in the study. A high response rate was achieved (82\%). All 820 participants of this study are primary school teachers from 11 different provinces throughout China. The sampling procedure initially took into account the teaching context of teachers (urban versus rural), the level of economic development of the provinces (developed versus developing), and the four school categories.

Additional criteria played a role, but did not define the further stratification strategy of the sample. Sample characteristics are summarised in Table 1.

Of all respondents, $70.1 \%$ of teachers were female. Respondents were grouped into three categories according to their years of teaching experience: teachers with less than 5 years of teaching experience (12.4\%); teachers with 6 to 15 years of teaching experience (46.2\%); and teachers with more than 16 years of teaching experience $(41.3 \%)$. Moreover, respondents were also categorised into four groups, depending upon their teaching subject, since subject curriculum and instruction are still preferable to integrated curriculum and instruction in the Chinese educational context: $63.3 \%$ of teachers teach an academic (main) subject (i.e. Chinese, English, mathematics, science); 19.9\% teach a non-academic (subsidiary) subject (i.e. fine arts, music, physical education, information technology); $13.5 \%$ teach more than one subject; 27 teachers (3.3\%) did not give an answer to the subjectrelated question. As to the school setting, 430 (52.4\%) teachers work in urban schools, whereas $390(47.6 \%)$ teachers work in rural schools. Furthermore, the schools of $418(51 \%)$ teachers are located in developed areas, and those of $402(49 \%)$ teachers are located in developing areas. Respondents can be located in one of the four different geographical 


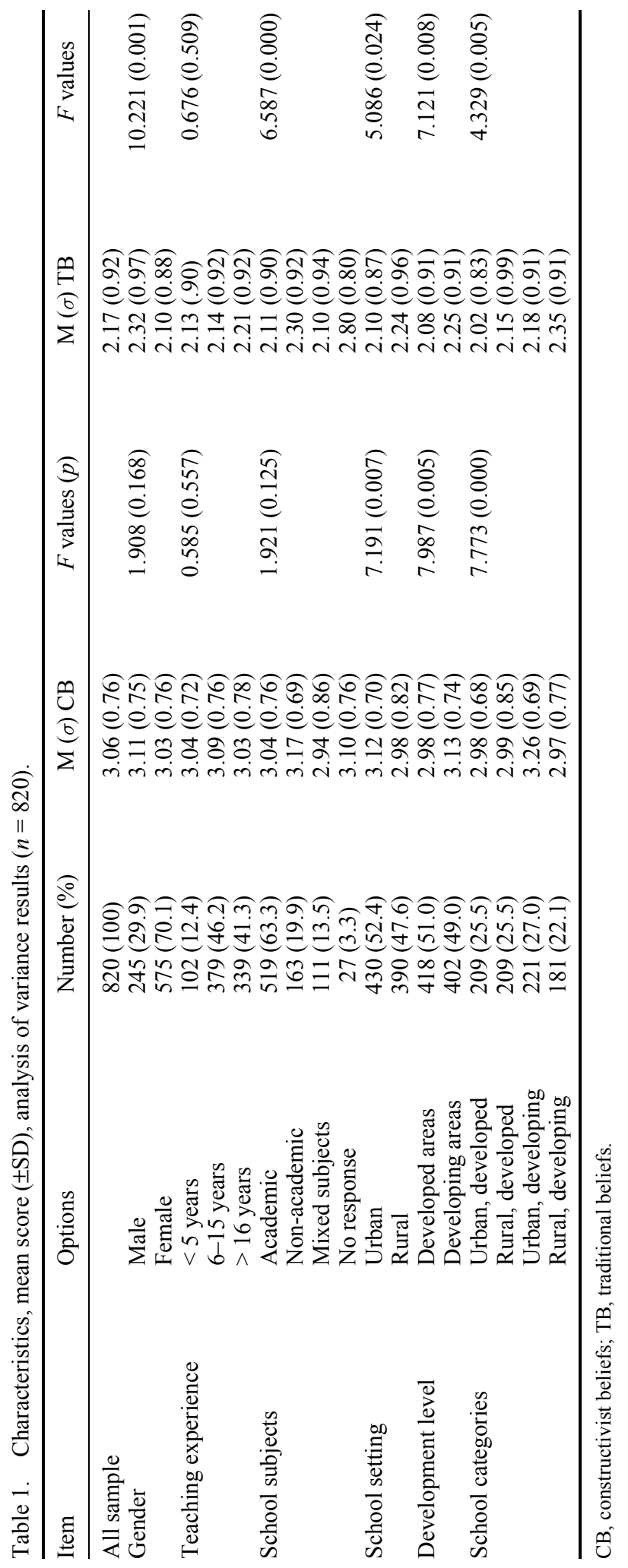


school types, which can be identified by combing urban/rural and developed/developing regions. Sample distributions of the four school categories are: teachers from urban schools in developed areas $(N=209 ; 25.5 \%)$; teachers from rural schools in developed areas $(N=209 ; 25.5 \%)$; teachers from urban schools in developing areas $(N=221 ; 27 \%)$; and teachers from rural schools in developing areas $(N=181 ; 22.1 \%)$.

\section{Data analysis}

Data analysis is based on: (1) analysis of descriptive statistics; (2) analysis of variance (ANOVA) tests to analyse differences in teachers' educational beliefs when considering endogenous and exogenous variables (see Table 1); (3) hierarchical cluster analysis and $\mathrm{K}$-mean cluster analysis to delineate teacher profiles of educational beliefs; and (4) crosstabulation to interpret the direction of differences according to school categories and teacher profiles.

\section{Results}

\section{The nature of teacher beliefs}

Table 1 also includes a clear overview of the extent to which teachers hold constructivist and traditional educational beliefs. In addition, the scores are split up according to endogenous and exogenous teacher characteristics. At a general level, the means of educational beliefs reflect that teachers report higher scores in relation to constructivist beliefs $(\bar{x}=3.06)$ when compared with traditional beliefs $(\bar{x}=2.17)$.

\section{Teacher beliefs and endogenous teacher characteristics}

Results of ANOVA analysis shows that male and female teachers do not differ in their adoption of constructivist beliefs $\left(F(1,818)=1.908, p>0.05, \eta^{2}=0.001\right)$. In contrast, significant differences are found in relation to traditional beliefs $(F(1,818)=10.221$, $\left.p=0.001, \eta^{2}=0.000\right)$, where male teachers adopt traditional beliefs to a significantly higher extent.

The number of years of teaching experience has no effect on adopting either constructivist beliefs $\left(F(2,817)=0.585, p>0.05, \eta^{2}=0.002\right)$ or traditional beliefs $(F(2,817)=$ $\left.0.676, p>0.05, \eta^{2}=0.002\right)$.

When studying the potential relationship between teachers' beliefs and the school subject they teach, we observe a significant difference in the extent teachers adhere to traditional beliefs $\left(F(3,816)=6.587, p<0.001, \eta^{2}=0.008\right)$. On the basis of a post hoc test (Scheffe) (and excluding those teachers who did not answer the subject-related question), traditional beliefs were adopted to a higher extent $(p<0.01)$. There was no significant difference observed in the adoption of constructivist beliefs $(F(3,816)=$ $\left.1.921, p>0.05, \eta^{2}=0.002\right)$.

\section{Teacher beliefs and exogenous variables}

For teachers from urban areas, we observed significantly higher scores in relation to constructivist beliefs $\left(F(1,818)=7.191, p<0.01, \eta^{2}=0.007\right)$ and significantly lower scores for traditional beliefs $\left(F(1,818)=5.086, p<0.05, \eta^{2}=0.003\right)$ when compared with teachers from rural areas. 
For teachers from developed areas, we found significantly lower scores in relation to constructivist beliefs $\left(F(1,818)=7.987, p<0.01, \eta^{2}=0.007\right)$ and traditional beliefs $(F(1,818)$ $\left.=7.121, p<0.01, \eta^{2}=0.007\right)$ when compared with teachers working in developing regions.

When considering the factor of the four school categories, ANOVA analysis shows that the variable school categories has a significant effect. This is true for both traditional beliefs $\left(F(3,816)=7.773, p<0.001, \eta^{2}=0.011\right)$ and constructivist beliefs $(F(3,816)=$ 4.329, $\left.p<0.01, \eta^{2}=0.014\right)$.

According to results of a post hoc test (Scheffe), we see that teachers from urban schools in developing areas hold constructivist beliefs to a significantly higher extent than teachers from the other areas $(p<0.001)$, and that teachers from rural schools in developing areas hold traditional beliefs to a significantly higher extent than teachers from urban schools and rural schools in developed areas $(p<0.001)$. No significant differences were observed between teachers from rural schools in developed areas and teachers from urban schools in developed areas or developing areas, and teachers from urban schools in developed areas and developing areas.

\section{Identifying profiles in teachers' educational beliefs}

To explore whether teachers can be clustered into homogenous subgroups, a hierarchical cluster analysis was conducted, using constructivist beliefs and traditional beliefs as variables. Ward's method, which is designed to optimise the minimum variance within clusters, was used as a clustering method (Aldenderfer \& Blashfield, 1984). The results suggest a four-cluster solution. Based on this solution, K-mean cluster analysis was applied to delineate clear teacher profiles. Out of a sample of 820 respondents, $235(28.7 \%)$ are classified as belonging to cluster 1, which is labelled 'constructivist profile'; 242 (29.5\%) are grouped in cluster 2, labelled 'mixed constructivist and traditional profile'; 260 (31.7\%) produce cluster 3, labelled 'traditional profile'; and the remaining 83 teachers $(10.1 \%)$ model cluster 4, labelled 'mixed low constructivist and traditional profile'.

\section{Linking teacher profiles and school categories}

The direction of differences for school categories and teacher profiles was interpreted using cross-tabulations. Figure 1 shows the distribution of teachers from the four school categories based on four clusters. Teachers from urban schools in developed areas mostly adopt a traditional profile $(N=88,42 \%)$ and constructivist profile $(N=71,34 \%)$. Most of the teachers $(N=72,35 \%)$ from rural schools in developed areas adopt a mixed constructivist/traditional profile. Teachers from urban schools in developing areas reflect the highest proportion of the mixed constructivist/traditional profile $(81,4 \%)$ and constructivist profile $(77,3 \%)$. As to teachers from rural schools in developing areas, they mostly mirror a traditional beliefs profile $(72,4 \%)$.

Table 2. Profiles in teachers' constructivist beliefs (CB) and traditional beliefs (TB).

\begin{tabular}{lcrr}
\hline Cluster no. & $N(\%)$ & CB $z$-score & TB $z$-score \\
\hline 1. Constructivist profile & $235(28.7 \%)$ & 2.83 & -2.82 \\
2. Constructivist/traditional profile & $242(29.5 \%)$ & 3.45 & 3.49 \\
3. Traditional profile & $260(31.7 \%)$ & -2.35 & 0.30 \\
4. Low constructivist/traditional profile & $83(10.1 \%)$ & -10.70 & -3.12 \\
\hline
\end{tabular}




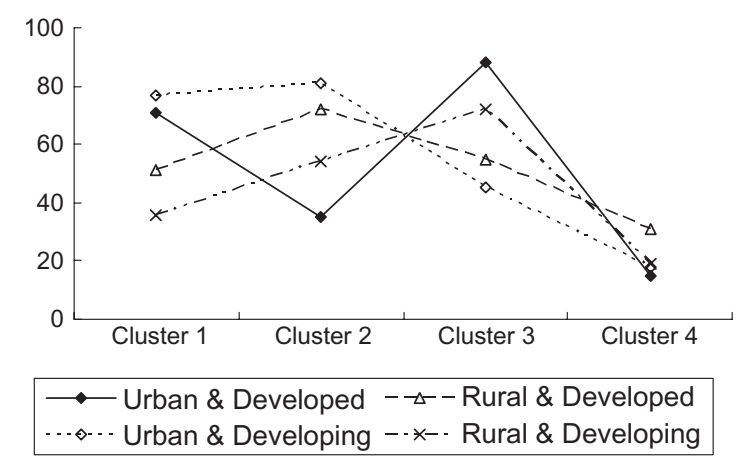

Figure 1. Distribution of teachers from the four school categories based on four clusters.

\section{Discussion}

The findings of the present study present an extensive profile of teachers' educational beliefs in Chinese primary schools.

\section{Teacher beliefs and endogenous variables: teacher characteristics}

In earlier studies, researchers found gender differences in the adoption of specific teachers' educational beliefs (e.g. Kalaian \& Freeman, 1994). The findings of the present study are in line with these earlier findings. Chinese male teachers hold traditional beliefs to a significantly higher extent, and hold constructivist beliefs to a slightly higher extent, but not significantly, when compared with Chinese female teachers.

Prior teaching experiences are expected to influence teachers' educational beliefs (Richardson, 1996). Previous studies in the Chinese setting indicate that teachers differ in their educational beliefs, depending on their years of teaching experience (Xie \& Ma, 2007). Lü (2004) states in this context that primary and secondary teachers with less than 6 years of teaching experience tend to hold more progressive educational beliefs. This could not be confirmed in the present study. When considering their teaching experience, teachers did not differ in their adoption of traditional or constructivist beliefs.

The relationship between curriculum subjects and teacher beliefs is confirmed when compared to the results of earlier studies. Researchers explored teachers' beliefs about mathematics (e.g. Renne, 1992), about science (e.g. Posner, Strike, Hewson \& Gertzog, 1982), and about language learning and teaching (e.g. Yang, 2000) etc. Lü (2004) has already pointed to significant differences in the general educational beliefs of teachers teaching different school subjects. In the present study, this is partly confirmed. Teachers teaching non-academic subjects mirror traditional beliefs to a statistically higher extent. Teaching academic or non-academic school subjects does - in the Chinese context - not yet result in differences in the adoption of constructivist beliefs.

\section{Teacher beliefs and exogenous variables: socioeconomic and geographical factors}

As mentioned earlier, owing to historical and economic reasons, there are large differences in educational levels between urban areas and rural areas, and between eastern, central and western Chinese provinces. The present findings mirror these differences. Chinese teachers from urban primary schools hold constructivist beliefs to a higher extent and mirror 
traditional beliefs to a lesser extent when compared with teachers from rural primary schools. This is in contrast to the findings of Lü and Wang (2004), who did not find a significant difference between teachers from urban schools and rural schools in China. This can be partly explained by the more diverse sample that was involved in the present study (which included 11 provinces).

Surprisingly, we observe that teachers working in developing areas hold constructivist beliefs to a higher extent than those working in developed areas. This inconsistent result can be partly explained as 'disenchantment' (Vandenberghe \& Huberman, 1999). Teachers in the basic education system of China have been provided a large amount of training in view of the implementation of the new curriculum reform in China. Teachers working in developed areas participated in the reform earlier than those in developing areas. However, after a vigorous period of reform implementation, the former group has encountered 'education reform fatigue' ( $\mathrm{Li}, 2008)$ and are suspicious of new educational theories.

\section{Teacher profiles of educational beliefs}

Four different beliefs-based profiles could be identified. Two relatively small subgroups of teachers take up an extreme position - they adopt dominantly constructivist beliefs $(28.7 \%)$ or mixed constructivist/traditional beliefs $(29.5 \%)$, respectively. The profile of mixed constructivist/traditional beliefs is a new finding in the Chinese context. However, in Western settings, researchers have already observed that some teachers hold both constructivist and traditional beliefs to a higher extent (e.g. Tondeur et al., 2008). As stated earlier, the bipolar distinction between teacher-centred 'traditionalistic' and student-centred 'progressive' beliefs has therefore been challenged (Kerlinger \& Kaya, 1959). Members of the largest subgroup (31.7\%) adopt traditional beliefs. Based on this finding, we may argue that most of the Chinese teachers still hold traditional beliefs. Finally, teachers in the smallest subgroup (10.1\%) adopt a mixed low constructivist/traditional profile. The latter profile is comparable to the one found in a recent study, set up in the Belgian context, and was labelled as an 'undefined profile' (Tondeur et al., 2008). Of importance is the fact that many teachers are able to hold opposing beliefs within their belief system. This finding is consistent with studies about conceptions of teaching (e.g. Pratt, 1992) and teachers' educational beliefs (Van Driel, Bulte \& Verloop, 2007). These sets of opposing beliefs are considered to be 'functional paradigms' (Lantz \& Kass, 1987) that are helpful to cater for very different situations in the learning and training settings.

\section{Linking teacher profiles and school categories}

The underlying influence of socioeconomic and geographical factors on teacher profiles was also examined by linking teacher profiles and school categories. A large number of teachers (42\%) from urban schools in developed areas fit the extremely traditional profile. As mentioned above, we may explain this by 'disenchantment' (Vandenberghe \& Huberman, $1999)$ and 'education reform fatigue' ( $\mathrm{Li}, 2008)$. The largest number of teachers $(35 \%)$ from rural schools in developed areas is linked to the mixed constructivist/traditional profile. According to Tondeur et al. (2008), this profile is positive to teachers' educational practice. Teachers from urban schools in developing areas possess the largest proportion following the constructivist profile (35\%) and mixed constructivist/traditional profile (37\%). This finding is supported by an earlier post hoc test result - teachers from urban schools in developing areas hold constructivist beliefs to a significantly higher extent. The largest number of teachers (40\%) from rural schools in developing areas can be linked to 
the traditional profile. A large body of evidence can be found for this finding (see, for example, Pei, 2004; Teng, 2003). For instance, Pei (2004) states that for primary school teachers in western regions of China, traditional instructional beliefs are still dominant.

\section{Limitations}

The design of the present study reflects some limitations. First, it is built only on self-reports. Qualitative methods (such as video analysis, classroom observation) should substantiate the present findings. A mixed research method of qualitative and quantitative should therefore be adopted for further studies. Second, the research instrument was originally developed by Western researchers in Western settings. Although much time and energy was put into the translation and adaptation of a new version, this version might still be less suitable for Chinese respondents (e.g. in the way questions were stated, or the way it reflects the Chinese context). This calls for the development of an instrument that is completely based on the Chinese educational setting. Third, the overall number of test items used to determine particular teacher educational beliefs was restricted. This may have affected the validity and reliability of the scale (Field, 2005). Finally, it should be noted that a large number of primary teachers in China hold strong traditional beliefs, although policy makers and teacher educators have been making efforts to promote progressive approaches to teachers (Pei, 2004). In future research, it might be interesting to know why traditional beliefs are so important in the Chinese setting, and thus explain this contradiction.

\section{Implications for policy development and teacher development}

The findings of the study are important in view of educational policy development, teacher education and teacher professional development.

First, educational policy makers should consider the gender differences of teachers and the differences in the developmental level of particular Chinese regions, since differences in school categories and gender differences of teachers go together with differences in teachers' educational beliefs.

Second, since teachers involved in the teaching of non-academic subjects mirror traditional beliefs to a higher extent, these teachers should be involved in professional development projects in view of developing a richer belief system that embraces both traditional and constructivist beliefs. Third, teachers' individual beliefs should be challenged since there is a clear connection between teachers' educational beliefs and their instructional practices (Ertmer 1999; Richardson, 1996). Nespor (1987) suggests that instructional change is not a matter of abandoning beliefs, but of gradually replacing or enriching them with belief systems that are relevant in view of the instructional context. In addition, it is stressed that these beliefs can best be influenced through concrete experiences in a supportive environment (Nespor, 1987). This introduces a dramatic change in the way professional development is to be set up; namely, towards a case-based, practice-orientated teacher education model.

\section{Conclusion}

In the present article, we explored the nature and structure of educational beliefs of Chinese teachers. Based on an adaptation of available instruments, an in-depth picture could be developed of the educational beliefs that are reported by teachers to play a role in their teaching practices. Comparable teacher characteristics help to explain differences between 
teachers. In contrast, we also see clear differences that reflect regional differences in China. Teachers from developed versus developing, and urban versus rural areas report differences in their educational beliefs. This could have been expected, considering the heterogeneous nature and status of school policy development between the different regions. Theoretically, our findings reinforce theories about teacher thinking processes, teacher education and curriculum reform in Chinese educational settings. Furthermore, based on research instruments developed in Western contexts, our empirical findings verify research findings about teachers' educational beliefs in Western contexts (Tondeur et al., 2008).

\section{Acknowledgements}

This study was supported by the Ghent University BOF Research Grant B/07287/01.

\section{Notes on contributors}

Dr Guoyuan Sang is a PhD researcher at the Department of Educational Studies, Ghent University, Belgium.

Professor Martin Valcke is Head of the Department at the Department of Educational Studies, Ghent University, Belgium.

Professor Johan van Braak is a tenured academic researcher at the Department of Educational Studies, Ghent University, Belgium.

Dr Jo Tondeur is a researcher at the Department of Educational Studies, Ghent University, Belgium.

\section{References}

Aldenderfer, M.S., \& Blashfield, R.K. (1984). Cluster analysis. Beverly Hills, CA: Sage.

Alexander, R.J. (2001). Border crossings: Towards a comparative pedagogy. Comparative Education, 37, 507-523.

Ashton, P.T. (1990). Editorial. Journal of Teacher Education, 41(1), 2.

Billig, M., Condor, S., Edwards, D., Gane, M., Middleton, D., \& Radley, A. (1988). Ideological dilemmas: A social psychology of everyday thinking. London: Sage.

Bramald, R., Hardman, F., \& Leat, D. (1995). Initial teacher trainees and their views of teaching and learning. Teaching and Teacher Education, 11, 23-31.

Brousseau, B.A., Book, C., \& Byers, J.L. (1988). Teacher beliefs and the cultures of teaching. Journal of Teacher Education, 39(6), 33-99.

Brown, C.A. (1985). A study of the socialization to teaching of a beginning secondary mathematics teacher. Unpublished doctoral dissertation. University of Georgia, Athens, USA.

Cao, K.H. (2006). Studies on teachers' daily classes. Language Teaching in Middle School, 12(4), $14-18$

The Central People's Government [CPG]. (2000). The Chinese Western Development Drive Policy. Retrieved May 27, 2007, from http://www.chinawest.gov.cn/web/index.asp

Clark, C.M., \& Peterson, P.L. (1986). Teachers' thought processes. In M.C. Wittrock (Ed.), Handbook of research on teaching (pp. 255-296). New York: Macmillan.

Correa, C.A., Perry, M., Sims, L.M., Miller, K.F., \& Fang G. (2008). Connected and culturally embedded beliefs: Chinese and US teachers talk about how their students best learn mathematics. Teaching and Teacher Education, 24, 140-153.

Erlwanger, S.H. (1975). Case studies of children's conceptions of mathematics. Journal of Children's Mathematical Behaviour, 1(3), 157-283.

Ernest, P. (1991). Philosophy of Mathematics education. London: Falmer.

Ertmer, P.A. (1999). Addressing first- and second-order barriers to change: Strategies for technology integration. Educational Technology Research and Development, 47(4), 47-61.

Field, A. (2005). Discovering statistics using SPSS. London: Sage. 
Fishbein, M., \& Ajzen, I. (1975). Belief, attitude, intention, and behavior: An introduction to theory and research. Reading, MA: Addison-Wesley.

Geng, W.X., Feng, C.M., Shen, J.L., \& Zhang, N. (2006). A study on differences of teacher beliefs in urban and rural areas. Educational Review, 3(6), 2-19.

Green, T.F. (1971). The activities of teaching. Tokyo: McGraw-Hill Kogakusha, Ltd.

Hambleton, R. (1992). Translating achievement tests for use in cross-national studies (Doc. Ref.: ICC454/NRC127). Paper prepared for the Third International Mathematics and Science Study (TIMSS).

Hermans, R., van Braak, J., \& Van Keer, H. (2008). Development of the beliefs about primary education scale: Distinguishing a developmental and transmissive dimension. Teaching and Teacher Education, 24(1), 127-139.

Kagan, D.M. (1992). Implications of research on teacher belief. Educational Psychologist, 27, 65-90.

Kalaian, H.A., \& Freeman, D.J. (1994). Gender differences in self-confidence and educational beliefs among secondary teacher candidates. Teaching and Teacher Education, 10(6), 47-58.

Kerlinger, F.N., \& Kaya, E. (1959). The construction and factor analytic validation of scales to measure attitudes toward education. Educational and Psychological Measurement, 19, 13-29.

Lantz, O., \& Kass, H. (1987). 'Chemistry teachers' functional paradigms. Science Education, 71, 117-134.

Leder, G.C., \& Forgasz, H.J. (2002). Measuring mathematical beliefs and their impact on the learning of mathematics. In G.C. Leder, E. Pehkonen and G. Törner (Eds), Beliefs: A hidden variable in mathematics education? (pp. 95-114). Dordrecht: Kluwer Academic Publishers.

Li, C.L. (2008). An analysis of education reform fatigue. Educational Development Studies, 9, $18-21$.

Lim, C. \& Torr, J. (2007). Singaporean early childhood teachers' beliefs about literacy development in a multilingual context. Asia-Pacific Journal of Teacher Education, 35(4), 409-434.

Lin, Q.C. (1992). Correlation research on primary school teachers' educational beliefs in Taiwan. Unpublished doctoral dissertation (in Chinese). Taiwan Political Normal University, Taiwan.

Lü, G.G. (2004). Research on teachers' beliefs and factors concerned. Unpublished doctoral thesis (in Chinese). Northwest Normal University, Lanzhou, China.

Lü, G.G., \& Wang, J.Y. (2004). A survey on teachers' beliefs about new curriculum in K-12. Modern Education Science, 13, 33-35.

Martin, N.K., \& Yin, Z.N. (1999). Beliefs regarding classroom management style: Differences between urban and rural secondary level teachers. Journal of Research in Rural Education, 15(2), 101-105.

Nespor, J. (1987). The role of beliefs in the practice of teaching. Journal of Curriculum Studies, 19(4), 317-328.

Pajares, F. (1992). Teachers' beliefs and educational research: Cleaning up a messy construct. Review of Educational Research, 62(3), 307-332.

Pei, D.N. (2004). The development and modernization of basic education in China. Peking University Education Review, 2, 63-69.

Posner, G.J., Strike, K.A., Hewson, P.W., \& Gertzog, W.A. (1982). Accommodation of a scientific conception: Toward a theory of conceptual change. Science Education, 66, 211-227.

Pratt, D.D. (1992). Chinese conceptions of learning and teaching: A Westerner's attempt at understanding. International Journal of Lifelong Education, 11(4), 301-319.

Renne, C.G. (1992, April). Elementary school teachers' views of knowledge pertaining to mathematics. Paper presented at the Annual Meeting of the American Research Association, San Francisco.

Richardson, V. (1996). The role of attitudes and beliefs in learning to teach. In J. Sikula (Ed.), Handbook of research on teacher education (pp. 102-119). New York: Simon \& Schuster Macmillan.

Samuelowicz, K., \& Bain, J.D. (1992). Conceptions of teaching held by academic teachers. Higher Education, 24, 93-111.

Schoenfeld, A.H. (1985). Mathematical problem solving. Orlando, FL: Academic Press.

Shaw, E.L., \& Cronin-Jones, L. (1989). Influence of methods instruction on pre-service elementary and secondary science teachers' beliefs. (ERIC Document Reproduction Service No. ED 318 639). Paper presented at the Annual meeting of Mid-South Educational Research Association (Little Rock, AR, November 7-10).

Shin, S., \& Koh, M. (2007). A cross-cultural study of teachers' beliefs and strategies on classroom behavior management in urban American and Korean school systems. Education and Urban Society, 39(2), 286-309. 
Stigler, J.W., \& Hiebert, J. (1999). The teaching gap: Best ideas from the world's teachers for improving education in the classroom. New York: Summit.

Teng, X. (2003). Ethnic groups, cultural diversities and diversification of school curriculum. Jiangsu Social Science, 3, 24-29.

Thompson, A.G. (1992). Teachers' beliefs and conceptions: A synthesis of the research. In D.A. Grouws (Ed.), Handbook of research on mathematics teaching and learning (pp. 127-146). New York: Macmillan.

Tobin, K., \& McRobbie, C.J. (1996). Cultural myths as constraints to the enacted science curriculum. Science Education, 80, 223-241.

Tondeur, J., Devos, G., Van Houtte, M., van Braak, J., \& Valcke, M. (2009). Understanding organisational and cultural school characteristics in relation to educational change: The case of ICT integration. Educational Studies, 35(2), 223-235.

Tondeur, J., Hermans, R., van Braak, J., \& Valcke, M. (2008). Exploring the link between teachers' educational beliefs profiles and different types of computer use in the classroom: The impact of teacher beliefs. Computers in Human Behavior, 24(6), 2541-2553.

Van Driel, J.H., Bulte, A.M.W., \& Verloop, N. (2007). The relationships between teachers' general beliefs about teaching and learning and their domain-specific curricular beliefs. Learning and Instruction, 17, 156-171.

Vandenberghe, R., \& Huberman, A.M. (Eds). (1999). Understanding and preventing teacher burnout: A sourcebook of international research and practice. Cambridge: Cambridge University Press.

Wood, E.F., \& Floden, R.E. (1990). Where teacher education students agree: Beliefs widely shared before teacher education. (ERIC Document Reproduction Service No. ED 331 781). Retrieved April 28, 2008, from http://www.eric.ed.gov/ERICDocs/data/ericdocs2sq1/content_storage_01/ $0000019 \mathrm{~b} / 80 / 22 / \mathrm{ea} / \mathrm{f} 2 . \mathrm{pdf}$

Woolley, S.L., Benjamin, W.J.J., \& Woolley, A.W. (2004). Construct validity of a self-report measure of teacher beliefs related to constructivist and traditional approaches to teaching and learning. Educational and Psychological Measurement, 64, 319-331.

Xie, Y. (2006). Teacher beliefs: 'The ghost' in the schooling. The case study of an ordinary middle school. Unpublished doctoral thesis (in Chinese). Northeast Normal University, Changchun, China.

Xie, Y., \& Ma, Y.P. (2007). The formation and change of teacher beliefs. Comparative Educational Studies, 28(6), 1-36.

Xiong, X.J. (2001). An exploratory study on teacher qualifications. Education Exploration, 11(3), $24-29$

Yang, N.D. (2000). Teachers' beliefs about language learning and teaching: A cross-cultural comparison. Texas Papers in Foreign Language Education, 5(1), 39-52.

Zahorik, J.A. (1987). Teachers' collegial interaction: An exploratory study. The Elementary School Journal, 87(4), 385-396.

Zhu, Y. (2003). The cultural causation of the differences of the urban and rural economy development of China. Exploring, 3, 24-32. 